\title{
ANKSIOZNOST STUDENATA FAKULTETA ZDRAVSTVENIH STUDIJA U MOSTARU PRIJE I NAKON ISPITA
}

\author{
Oliver Ljubić, Dragan Babić \\ Fakultet zdravstvenih studija, Sveučilište u Mostaru, 88000 Bosna i Hercegovina \\ Rad je primljen 7.3.2017. Rad je recenziran 23.3.2017. Rad je prihvaćen 5.4.2017.
}

\section{SAŽETAK}

UVOD: Anksioznost predstavlja skupinu različitih medicinskih stanja u kojima dominira zabrinutost, strah, tjeskoba, strepnja, napetost ili nemir. Javlja se u raznim životnim situacijama, a vrlo je česta kod studenata u vrijeme ispita.

CILJ: Ispitati anksioznost studenata Fakulteta Zdravstvenih studija u Mostaru, prije i nakon ispita.

ISPITANICI I METODE: Ispitivanje je obuhvatilo prigodan uzorak od 200 studenata svih pet studijskih godina i smjerova Fakulteta zdravstvenih studija u Mostaru. Ispitanicima je na dan ispita ponuđen Upitnik anksioznosti kao stanja osobine i ličnosti (STAI) koji su trebali popuniti. Nakon popunjavanja prvog dijela upitnika, sa svakim ispitanikom zasebno je dogovoren ponovni susret nakon $24 \mathrm{~h}$, u svrhu popunjavanja drugog dijela upitnika.

REZULTATI: Obrađeni su rezultati 200 ispitanika. Muških ispitanika bilo je 88 (44,0 \%), dok je ženskih ispitanika bilo 76 (51,6 \%). Prosječna životna dob ispitanika bila je $22,9 \pm 1,7$ godina.

Prosječna vrijednost odgovora dobivenih na ljestvici stanja anksioznosti u ispitanika prije pristupanja ispitu iznosila je $50,1 \pm 6,1$ bodova, dok je na ljestvici anksioznosti kao osobine, nakon 24 sata od ispita, iznosila 48,6 $\pm 7,1$ bodova, što se pokazalo statistički značajnim $(\mathrm{p}=0,020)$.

ZAKLJUČAK: Statistički značajno veća anksioznost postoji kod studenata prije ispita nego poslije ispita. Razina anksioznosti kao stanja ličnosti u ispitanika pokazala se statistički značajno veća u odnosu na anksioznost kao osobine ličnosti.

Ključne riječi: anksioznost, studenti, Fakultet zdravstvenih studija

Osoba za razmjenu informacija:

Oliver Ljubić, mag. med. tech.

e-mail: oliver_m0@hotmail.com

\section{UVOD}

Anksioznost predstavlja skupinu različitih medicinskih stanja u kojima dominira zabrinutost, strah, tjeskoba, strepnja, napetost ili nemir. Ima veliko medicinsko, socijalno i ekonomsko značenje zbog svoje velike učestalosti, negativnog utjecaja na kvalitetu života, radno i socijalno funkcioniranje te velikih indirektnih i direktnih troškova (1). Anksioznost se očituje strahom od stanovite jasno definirane situacije i objekta koji objektivno nije opasan i ugrožavajući, a ispoljava se izbjegavajućim ponašanjem i doživljavanjem straha od mogućeg susreta s njim.
Osobe su svjesne nerealnosti i nelogičnosti straha, ali nisu u stanju naći prikladna objašnjenja za njegov nastanak niti se suočiti sa zastrašujućim situacijama i objektima (2).

U suvremenom društvu i svakodnevnom životu često smo izloženi različitim situacijama ispitivanja, testiranja te provjere sposobnosti i znanja, a o kojima u određenoj mjeri ovisi naša budućnost. Gotovo da nema osobe koja se u životu nije barem jednom susrela s nekim oblikom ispitivanja ili testiranja $\mathrm{u}$ školi, na fakultetu, u situacijama profesionalne 
orijentacije i selekcije ili na radnom mjestu. U nekih se osoba u takvim situacijama može javljati ispitna anksioznost.

Strah od ispita, odnosno ispitna anksioznost definira se kao složeni multidimenzionalni konstrukt koji uključuje kognitivne, afektivne, fiziološke i ponašajne reakcije na evaluativne situacije. Smatra se posebnim oblikom opće anksioznosti koja se javlja $\mathrm{u}$ ispitnim situacijama. Ispitna anksioznost javlja se u svakodnevnim životnim situacijama, u ljudi svih dobnih razina, u situacijama kad se ocjenjuju, procjenjuju naše sposobnosti, postignuća i interesi.

Više autora dalo je svoje određenje ispitne anksioznosti. Ispitna anksioznost je forma situacijske anksioznosti. Obilježavaju je stres i nelagoda izražena u ispitnoj situaciji, uz izraženu percepciju bespomoćnosti. Može se odnositi na emocionalno stanje ili na crtu ličnosti. Postala je jedan od najviše ometajućih čimbenika u školi. Oko 30 \% učenika ima izraženiju anksioznost koja ih ometa u svakodnevnom radu (3).

Prema Spielbergerovoj koncepciji anksioznosti, ispitna anksioznost se može javljati kao stanje ili kao osobina ličnosti. U slučaju ispitne anksioznosti kao stanja ona se odnosi na prolazno emocionalno stanje, a javlja se kad pojedinac percipira stvarne ili zamišljene podražaje vezane uz situacije ispitivanja kao prijeteće ili opasne, te na njih reagira napetošću, aktivacijom autonomnog živčanog sustava i zabrinutošću. Ispitna anksioznost kao osobina predstavlja relativno stabilnu značajku ličnosti pri čemu se mnoštvo podražaja vezanih uz ispitne situacije percipira kao ozbiljna osobna prijetnja uz tendenciju reagiranja intenzivnim anksioznim stanjem (4). Što osoba ima izraženiju osobinu ispitne anksioznosti, to se $s$ većom sigurnošću može predvidjeti da će ona $\mathrm{u}$ ispitnim situacijama reagirati intenzivnijim stanjem anksioznosti.

Kada se ispitna anksioznost prvi puta javlja, ne može se sa sigurnošću odrediti, iako postoji pretpostavka da se javlja između sedme i petnaeste godine (5). Intenzitet ispitne anksioznosti raste $\mathrm{u}$ funkciji dobi prateći krivulju negativne akceleracije: prvo naglo raste, nakon čega se njezin rast usporava te se na kraju oko osamnaeste godine stabilizira na dostignutoj razini. Te promjene se odvijaju paralelno s promjenama u kognitivnom razvoju. Razvijenije logičko mišljenje omogućuje bolje predviđanje mogućih povreda samopoštovanja. Porast ispitne anksioznosti u funkciji dobi se također pokušava objasniti činjenicom da stariji učenici pokazuju i manje strahova od npr. životinja, mraka, grmljavine i sl., ali zato više strahova od tjelesnih povreda, neugodnosti u društvu, te od neuspjeha u nekim aktivnostima, a koji bi mogli biti relevantni za pojavu ispitne anksioznosti (6). Međutim, rezultati istraživanja u tom području nisu u potpunosti konzistentni. U određenog broja učenika ispitna anksioznost se javlja tek u srednjoj školi ili čak na fakultetu što se može tumačiti činjenicom da dolazak u novu sredinu, koja je manje „zaštitnička“, izaziva latentnu ispitnu anksioznost koja se tek tada počinje manifestirati (7).

\section{CILJ}

Ispitati anksioznost studenata Fakulteta Zdravstvenih studija u Mostaru, prije i nakon ispita.

\section{ISPITANICI | METODE}

Ispitivanje je obuhvatilo prigodan uzorak od 200 studenata svih pet studijskih godina i smjerova Fakulteta zdravstvenih studija u Mostaru. Ispitanici su u rasponu životne dobi od 19 do 40 godina, pri

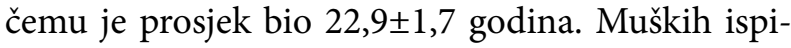
tanika bilo je 88 (44,0 \%), dok je ženskih ispitanika bilo $112(56,0 \%)$.

Ispitanicima je na dan njihovih pristupanja ispitu ponuđen prvi dio upitnika, kojim se mjeri anksioznost kao stanje, koji su trebali popuniti. Prije same primjene upitnika studentima je naglašeno kako je istraživanje u potpunosti anonimno i kako će se podatci koristiti isključivo za potrebe izrade znanstvenog rada. Zamoljeni su za potpunu suradnju i iskrenost. Rečeno im je da tvrdnje predstavljaju opis nekih uobičajenih reakcija, stavova, ponašanja i doživljavanja ljudi, te da izraze svoj stupanj slaganja sa svakom od tvrdnji. Ispitivanje je u prosjeku trajalo između 15 i 20 minuta. Svaki je upitnik imao zasebnu uputu. Nakon popunjavanja upitnika, sa svakim ispitanikom zasebno, dogovoren je ponovni susret 
nakon 24 sata, u svrhu popunjavanja drugog dijela upitnika, kojim se mjeri anksioznost kao osobina ličnosti.

\section{Instrument istraživanja}

Upitnik anksioznosti kao stanja i osobine ličnosti - STAI (engl. State-Trait Anxiety Inventory) konstruiran je na temelju Spielbergerovih postavki o razlikovanju anksioznosti kao stanja i kao osobine ličnosti. Sastoji se od dviju odvojenih ljestvica za samoprocjenu, namijenjenih utvrđivanju anksioznosti kao stanja i osobine. Ljestvica stanja anksioznosti (S ljestvica ili Oblik 1-M) sadrži 20 tvrdnji kojima se procjenjuje kako se ispitanik osjeća sada, u ovom trenutku. Ljestvica anksioznosti kao osobine (O ljestvica ili Oblik 2-M) ima 20 tvrdnji kojima se mjeri kako se ispitanik općenito osjeća. Ispitanikov je zadatak da uz svaku tvrdnju zaokruži jedan odgovor na skali od 4 stupnja koji najbolje opisuje njegovo trenutačno ili općenito stanje (za S-ljestvicu: 1 uopće ne, 2-malo, 3-umjereno i 4-jako, a za O-ljestvicu: 1-gotovo nikada, 2-katkada, 3 često i 4-gotovo uvijek). Upitnik je namijenjen pojedinačnoj i skupnoj primjeni, a ispunjavanje upitnika nije vremenski ograničeno. Ukupan rezultat se dobiva tako da se zbroje bodovi za svih 20 tvrdnji za svaku ljestvicu pojedinačno. Najmanji mogući rezultat je 20 , a najveći mogući 80 (8).

Ljestvicom stanja anksioznosti procjenjuju se bitna obilježja tog stanja: strepnja, napetost, nervoza i zabrinutost. Osim za utvrđivanje kako se ljudi osjećaju upravo sada, može se upotrijebiti i za procjenu nečijeg stanja anksioznosti u različitim zamišljenim situacijama, situacijama iz prošlosti ili budućnosti. Utvrđeno je i da je S-ljestvica osjetljiv pokazatelj prolazne anksioznosti koju klijenti doživljavaju u savjetovališnom radu, psihoterapiji, ali i kao pokazatelj razine anksioznosti pri suočavanju s neizbježivim stresorima iz svakodnevnog života. Ljestvica anksioznosti kao osobine često je primjenjivana u procjeni kliničke anksioznosti ljudi s tjelesnim, psihofizičkim i psihijatrijskim oboljenjima, ali i procjeni anksioznosti srednjoškolaca, studenata i sl. U kliničkim i eksperimentalnim istraživanjima pokazala se korisnom u otkrivanju povišene razine neurotske anksioznosti (8).

\section{Statistička obradba podataka}

Raspodjela kontinuiranih podataka bila je simetrična, te smo za prikaz srednje vrijednosti i mjere raspršenja koristili aritmetičku sredinu i standardnu devijaciju. Pri usporedbi kontinuiranih varijabli, zbog simetričnosti podataka, korišten je t-test za nezavisne uzorke. Za statističku analizu rabljen je programski sustav SPSS for Windows (inačica 13.0, SPSS Inc, Chicago, Illinois, SAD) i Microsoft Excell (inačica 11. Microsoft Corporation, Redmond, WA, SAD).

Prikupljeni podatci obrađeni su pomoću metoda deskriptivne statistike. Distribucija vjerojatnosti kvantitativnih varijabli testirana je na normalnost Smirnov-Kolmogorovljevim testom te je ustanovljena normalnost raspodjele. Za prikaz srednje vrijednosti i mjere raspršenja korištena je aritmetička sredina i standardna devijacija te je za utvrđivanje razlika među skupinama rabljen sudentov t-test. $\mathrm{Za}$ analizu nominalnih varijabli korišten je $\chi^{2}$ test. $\mathrm{Za}$ statističku analizu dobivenih podataka rabljen je programski sustav SPSS for Windows (inačica 13.0, SPSS Inc, Chicago, Illinois, SAD) i Microsoft Excell (inačica Office 2007, Microsoft Corporation, Redmond, WA, SAD).

\section{REZULTATI}

Obrađeni su rezultati 200 ispitanika. Muških ispitanika bilo je 88 (44,0 \%), dok je ženskih ispitanika bilo 76 (51,6 \%). Prosječna životna dob ispitanika bila je $22,9 \pm 1,7$ godina. Ukupno $44(22,0 \%)$ ispitanika je na prvoj godini fakulteta, 47 (23,5\%) ispitanika na drugoj godini, $54(27,0 \%)$ na trećoj godini, $33(16,5 \%)$ na četvrtoj te $32(16,0 \%)$ na petoj godini fakulteta. Prosjek ocjena do 3 imalo je 50 (25,0 \%) ispitanika, $124(62,0 \%)$ imalo je prosjek ocjena 3 do 4 te 26 $(13,0 \%)$ ispitanika prosjek ocjena 4 do 5 . Broj studenata koji živi s roditeljima iznosio je $96(48,0 \%)$ te $104(52,0 \%)$ ispitanika koji tijekom studija ne žive s roditeljima. Ukupno 31 (15,5\%) ispitanik ocijenio je svoje materijalno stanje lošim, 94 (47,0 \%) srednjim te $75(37,5 \%)$ ispitanika koji su svoje materijalno 
stanje ocijenili dobrim. Broj pušača među ispitanicima iznosi 81 (40,5\%), dok broj onih koji povremeno konzumiraju alkohol iznosi 131 (65,5\%). Ukupno 12 (6\%) ispitanika navodi da povremeno konzumiraju psihoaktivne tvari (Tablica 1).

Tablica 1. Sociodemografske značajke ispitanika

\begin{tabular}{lcccc}
\hline Varijabla & $\begin{array}{c}\text { Broj ispitanika } \\
(\mathrm{n}=200)\end{array}$ & $\%$ & $\chi^{2}$ & $p$ \\
\hline Spol & & & & \\
\multicolumn{1}{c}{ mǔ̌ki } & 88 & 44,0 & 0,588 & 0,380 \\
ženski & 112 & 56,0 & & \\
\hline
\end{tabular}

Studijiska godina

\begin{tabular}{lllll} 
prva & 44 & 22,0 & & \\
druga & 47 & 23,5 & 8,429 & 0,077 \\
tré́a & 54 & 27,0 & & \\
četvrta & 33 & 16,5 & & \\
peta & 32 & 16,0 & & \\
\hline
\end{tabular}

\begin{tabular}{|c|c|c|c|c|}
\hline \multicolumn{5}{|l|}{ Prosjek ocjena } \\
\hline$<3$ & 50 & 25,0 & 78,270 & $<0,05$ \\
\hline $3-4$ & 124 & 62,0 & & \\
\hline$>4$ & 26 & 13,0 & & \\
\hline
\end{tabular}

\begin{tabular}{lrrrr}
\hline Stanovanje & & & & \\
- kod roditelja & 96 & 48,0 & 0,320 & 0,571 \\
- ostalo (podstanar, stu- & 104 & 52,0 & & \\
$\quad$ dentski dom, rodbina) & & & & \\
\hline
\end{tabular}

\begin{tabular}{ccccc}
\hline Ekonomski status & & & & \\
loš & 31 & 15,5 & 31,330 & $<0,05$ \\
srednji & 94 & 47,0 & & \\
dobar & 75 & 37,5 & & \\
\hline
\end{tabular}

\begin{tabular}{crrrr}
\hline $\begin{array}{c}\text { Pušenje cigareta } \\
\text { dd }\end{array}$ & & & & \\
ne & 81 & 40,5 & 7,220 & 0,007 \\
\hline
\end{tabular}

Povremena uporaba

alkoholnih pića

\begin{tabular}{crrrr} 
da & 131 & 65,5 & 19,230 & $<0,05$ \\
ne & 69 & 34,5 & & \\
\hline $\begin{array}{l}\text { Povremena uporaba } \\
\text { psihoaktivnih sredstava }\end{array}$ & & & & \\
da & 12 & 6,0 & 154,880 & $<0,05$ \\
ne & 188 & 94,0 & & \\
\hline
\end{tabular}

Prosječna vrijednost odgovora dobivenih na ljestvici stanja anksioznosti $\mathrm{u}$ ispitanika prije pristupanja ispitu iznosila je 50,1 $\pm 6,1$ bodova, dok je na ljestvici anksioznosti kao osobine nakon 24 sata od ispita iznosila $48,6 \pm 7,1$ bodova, što se pokazalo statistički značajnim $(\mathrm{p}=0,020)$ (Tablica 2$)$.
Tablica 2. Vrijednosti rezultata postignutih u Upitni$k u$ anksioznosti kao stanja $i$ anksioznosti kao osobine u studenata anketiranih uoči te dan poslije pristupanja ispitu

\begin{tabular}{lcccccc}
\hline Anksioznost & N & $\begin{array}{c}\text { Minimalna } \\
\text { vrijednost }\end{array}$ & $\begin{array}{c}\text { Maksimalna } \\
\text { vrijednost }\end{array}$ & M-SD* $^{*}$ & t-test & $p$ \\
\hline $\begin{array}{l}\text { Prije pristupanja } \\
\text { ispitu }\end{array}$ & 200 & 35 & 68 & $50,1-6,1$ & & \\
\hline $\begin{array}{l}\text { Nakon pristupanja } \\
\text { ispitu }\end{array}$ & 200 & 33 & 80 & 48,335 & 0,020 \\
\hline
\end{tabular}

${ }^{\star} \mathrm{M} \pm \mathrm{SD}$ : aritmetička sredina \pm standardna devijacija

Usporedbom rezultata upitnika u odnosu na spol ispitanika pokazala se statistički značajna razlika. Studentice su na ljestvici stanja anksioznosti dale prosječnu vrijednost odgovora $49,6 \pm 5,9$ bodova, a na ljestvici anksioznosti kao osobine prosječna vrijednost njihovog odgovora iznosila je $47,3 \pm 6,2$ bodova, što se pokazalo statistički značajno (Tablica 3 ).

Tablica 3. Vrijednosti rezultata postignutih u Upitni$k u$ anksioznosti kao stanja $i$ anksioznosti kao osobine u studenata prema spolu

\begin{tabular}{|c|c|c|c|c|c|}
\hline \multirow[b]{2}{*}{ Spol } & \multirow[b]{2}{*}{$\mathrm{N}$} & \multicolumn{2}{|c|}{ M-SD* razine anksioznosti } & \multirow[b]{2}{*}{ t-test } & \multirow[b]{2}{*}{$p$} \\
\hline & & $\begin{array}{c}\text { anksioznost kao } \\
\text { stanje ličnosti }\end{array}$ & $\begin{array}{l}\text { anksioznost } \\
\text { kao osobina } \\
\text { ličnosti }\end{array}$ & & \\
\hline Muški & 88 & $51,5-6,5$ & $52,8-8,1$ & 0,848 & 0,399 \\
\hline Ženski & 112 & $49,6-5,9$ & $47,3-6,2$ & 3,379 & 0,001 \\
\hline \multicolumn{6}{|c|}{${ }^{\star} \mathrm{M} \pm \mathrm{SD}:$ aritmetička sredina \pm standardna devijacija } \\
\hline \multicolumn{6}{|c|}{$\begin{array}{l}\text { Usporedbom rezultata upitnika u odnosu na stu- } \\
\text { ijsku godinu fakulteta nije se pokazala statistički } \\
\text { hačajna razlika (Tablica } 4 \text { ). }\end{array}$} \\
\hline
\end{tabular}


Tablica 4. Vrijednosti rezultata postignutih u Upitni$k u$ anksioznosti kao stanja $i$ anksioznosti kao osobine u studenata prema studijskoj godini fakulteta

\begin{tabular}{|c|c|c|c|c|c|}
\hline \multirow[b]{2}{*}{$\begin{array}{l}\text { Studijska } \\
\text { godina }\end{array}$} & \multirow[b]{2}{*}{$\mathrm{N}$} & \multicolumn{2}{|c|}{ M-SD* razine anksioznosti } & \multirow[b]{2}{*}{ t-test } & \multirow[b]{2}{*}{$p$} \\
\hline & & $\begin{array}{c}\text { anksioznost kao } \\
\text { stanje ličnosti }\end{array}$ & $\begin{array}{c}\text { anksioznost } \\
\text { ka0 osobina } \\
\text { ličnosti }\end{array}$ & & \\
\hline Prva & 44 & $50,5-5,9$ & $49,7-5,2$ & 0,683 & 0,496 \\
\hline Druga & 47 & $50,8-5,5$ & $49,4-6,2$ & 1,213 & 0,228 \\
\hline Treća & 54 & $49,3-6,2$ & $49,1-5,9$ & 0,720 & 0,899 \\
\hline Četvrta & 33 & $50,3-7,1$ & $49,7-6,9$ & 0,847 & 0,794 \\
\hline Peta & 32 & $49,6-6,0$ & $48,7-9,1$ & 0,378 & 0,708 \\
\hline
\end{tabular}

${ }^{*} \mathrm{M} \pm \mathrm{SD}$ : aritmetička sredina \pm standardna devijacija

Usporedbom rezultata upitnika u odnosu prosječnu vrijednost ocjena u ispitanika pokazala se statistički značajna razlika. Ispitanici s prosječnom ocjenom 4 i više na ljestvici stanja anksioznosti su dali prosječnu vrijednost odgovora $51,3 \pm 5,6$ bodova, a na ljestvici anksioznosti kao osobine prosječna vrijednost njihovog odgovora iznosila je $47,5 \pm 6,7$ bodova, što se pokazalo statistički značajno (Tablica 5).

Tablica 5. Vrijednosti rezultata postignutih u Upitni$k u$ anksioznosti kao stanja $i$ kao osobine u studenata Fakulteta Zdravstvenih studija Sveučilišta u Mostaru prema njihovom akademskom uspjehu.

\begin{tabular}{cccccc}
\hline \multirow{2}{*}{$\begin{array}{l}\text { Prosječna } \\
\text { vrijednost ocjena u } \\
\text { ispitanika }\end{array}$} & $N$ & \multicolumn{2}{c}{ M-SD* razine anksioznosti } & & \\
\cline { 3 - 5 } & & $\begin{array}{c}\text { anksioznost } \\
\text { kao stanje } \\
\text { ličnosti }\end{array}$ & $\begin{array}{c}\text { anksioznost } \\
\text { kao osobina } \\
\text { ličnosti }\end{array}$ & & \\
\hline 3 & 50 & $51,4-5,8$ & $50,4-5,8$ & 0,873 & 0,385 \\
\hline $3-4$ & 124 & $49,3-6,2$ & $48,7-6,1$ & 0,773 & 0,440 \\
\hline$>4$ & 26 & $51,3-5,6$ & $47,5-6,7$ & 2,179 & $\mathbf{0 , 0 1 4}$ \\
\hline
\end{tabular}

${ }^{\star} \mathrm{M} \pm \mathrm{SD}$ : aritmetička sredina \pm standardna devijacija

Ispitanici koji tijekom studiranja ne stanuju kod roditelja na ljestvici stanja anksioznosti dali su prosječnu vrijednost odgovora $51,5 \pm 6,0$ bodova, a na ljestvici anksioznosti kao osobine prosječna vrijednost njihovog odgovora iznosila je $47,2 \pm 6,5$ bodova, što se pokazalo statistički značajno (Tablica 6).
Tablica 6. Vrijednosti rezultata postignutih u Upitni$k u$ anksioznosti kao stanja i anksioznosti kao osobine u studenata prema načinu stanovanja.

\begin{tabular}{|c|c|c|c|c|c|}
\hline \multirow[b]{2}{*}{$\begin{array}{l}\text { Način stanovanja } \\
\text { tijekom studija }\end{array}$} & \multirow[b]{2}{*}{$\mathrm{N}$} & \multicolumn{2}{|c|}{ M-SD* razine anksioznosti } & \multirow[b]{2}{*}{ t-test } & \multirow[b]{2}{*}{$p$} \\
\hline & & $\begin{array}{l}\text { anksioznost } \\
\text { kao stanje } \\
\text { ličnosti }\end{array}$ & $\begin{array}{l}\text { anksioznost } \\
\text { kao osobina } \\
\text { ličnosti }\end{array}$ & & \\
\hline Kod roditelja & 96 & $49,5-6,2$ & $48,6-6,0$ & 1,014 & 0,312 \\
\hline $\begin{array}{l}\text { Ostalo (podstanar, } \\
\text { studentski dom, } \\
\text { rodbina) }\end{array}$ & 104 & $51,5-6,0$ & $47,2-6,5$ & 2,226 & 0,011 \\
\hline $\begin{array}{l}{ }^{*} \mathrm{M} \pm \mathrm{SD} \text { : arit } \\
\text { Usporedb } \\
\text { terijalni stat } \\
\text { razlika (Tabl }\end{array}$ & 7). & $\begin{array}{l}\text { sredina } \\
\text { ltata up }\end{array}$ & $\begin{array}{l}\text { standarc } \\
\text { nika u o } \\
\text { la statis }\end{array}$ & nos & $\begin{array}{l}\text { acija } \\
\text { a ma- } \\
\text { ačajna }\end{array}$ \\
\hline
\end{tabular}

Tablica 7. Vrijednosti rezultata postignutih u Upitni$k u$ anksioznosti kao stanja $i$ anksioznosti kao osobine u studenata prema materijalnom statusu.

\begin{tabular}{cccccc}
\hline & & \multicolumn{2}{c}{ M-SD* razine anksioznosti } & & \\
\cline { 3 - 4 } Materijalni status & $N$ & $\begin{array}{c}\text { anksioznost } \\
\text { ka0 stanje } \\
\text { ličnosti }\end{array}$ & $\begin{array}{c}\text { anksioznost } \\
\text { ka0 0sobina } \\
\text { ličnosti }\end{array}$ & t-test & $p$ \\
\hline Loš & 31 & $48,3-5,2$ & $50,5-5,1$ & $-1,063$ & 0,299 \\
\hline Srednji & 94 & $50,2-5,9$ & $50,0-6,4$ & 0,270 & 0,787 \\
\hline Dobar & 75 & $50,3-5,5$ & $51,4-6,3$ & 0,821 & 0,356 \\
\hline
\end{tabular}

${ }^{*} \mathrm{M} \pm \mathrm{SD}$ : aritmetička sredina \pm standardna devijacija

Usporedbom rezultata upitnika u odnosu na pušački status nije se pokazala statistički značajna razlika (Tablica 8).

Tablica 8. Vrijednosti rezultata postignutih u Upitni$k u$ anksioznosti kao stanja $i$ anksioznosti kao osobine u studenata prema pušačkom statusu

\begin{tabular}{|c|c|c|c|c|c|}
\hline \multirow[b]{2}{*}{ Pušenje cigareta } & \multirow[b]{2}{*}{$\mathrm{N}$} & \multicolumn{2}{|c|}{ M-SD* razine anksioznosti } & \multirow[b]{2}{*}{ t-test } & \multirow[b]{2}{*}{$p$} \\
\hline & & $\begin{array}{c}\text { anksioznost } \\
\text { kao stanje } \\
\text { ličnosti }\end{array}$ & $\begin{array}{c}\text { anksioznost } \\
\text { kao osobina } \\
\text { ličnosti }\end{array}$ & & \\
\hline $\mathrm{Da}$ & 81 & $51,1-5,9$ & $50,9-6,8$ & 1,014 & 0,312 \\
\hline $\mathrm{Ne}$ & 119 & $49,4-6,1$ & $48,9-6,2$ & 0,643 & 0,521 \\
\hline
\end{tabular}

${ }^{\star} \mathrm{M} \pm \mathrm{SD}$ : aritmetička sredina \pm standardna devijacija 
Usporedbom rezultata upitnika u odnosu na naviku uzimanja alkoholnih pića nije se pokazala statistički značajna razlika (Tablica 9).

Tablica 9. Vrijednosti rezultata postignutih u Upitni$k u$ anksioznosti kao stanja $i$ anksioznosti kao osobine u studenata prema navici uporabe alkoholnih pića.

\begin{tabular}{|c|c|c|c|c|c|}
\hline \multirow[b]{2}{*}{$\begin{array}{l}\text { Povremena uporaba } \\
\text { alkoholnih píca }\end{array}$} & \multirow[b]{2}{*}{$\mathrm{N}$} & \multicolumn{2}{|c|}{ M-SD* razine anksioznosti } & \multirow[b]{2}{*}{ t-test } & \multirow[b]{2}{*}{$\mathrm{p}$} \\
\hline & & $\begin{array}{l}\text { anksioznost } \\
\text { kao stanje } \\
\text { ličnosti }\end{array}$ & $\begin{array}{l}\text { anksioznost } \\
\text { kao osobina } \\
\text { ličnosti }\end{array}$ & & \\
\hline $\mathrm{Da}$ & 131 & $50,5-6,1$ & $50,4-6,8$ & 0,161 & 0,872 \\
\hline Ne & 69 & $49,2-6,0$ & $48,4-6,2$ & 0,818 & 0,415 \\
\hline
\end{tabular}

${ }^{\star} \mathrm{M} \pm \mathrm{SD}$ : aritmetička sredina \pm standardna devijacija

Usporedbom rezultata upitnika u odnosu na naviku uzimanja psihoaktivnih tvari nije se pokazala statistički značajna razlika (tablica 10).

Tablica 10. Vrijednosti rezultata postignutih u Upitniku anksioznosti kao stanja $i$ anksioznosti kao osobine u studenata prema navici uporabe psihoaktivnih tvari

\begin{tabular}{|c|c|c|c|c|c|}
\hline \multirow[b]{2}{*}{$\begin{array}{l}\text { Povremena uporaba } \\
\text { psihoaktivnih tvari }\end{array}$} & \multirow[b]{2}{*}{ N } & \multicolumn{2}{|c|}{ M-SD* razine anksioznosti } & \multirow[b]{2}{*}{ t-test } & \multirow[b]{2}{*}{$p$} \\
\hline & & $\begin{array}{c}\text { anksioznost } \\
\text { kao stanje } \\
\text { ličnosti }\end{array}$ & $\begin{array}{c}\text { anksioznost } \\
\text { kao osobina } \\
\text { ličnosti }\end{array}$ & & \\
\hline $\mathrm{Da}$ & 12 & $51,4-4,2$ & $51,1-4,0$ & 0,196 & 0,846 \\
\hline $\mathrm{Ne}$ & 188 & $50,0-6,1$ & $49,6-6,8$ & 0,568 & 0,570 \\
\hline
\end{tabular}

${ }^{\star} \mathrm{M} \pm \mathrm{SD}$ : aritmetička sredina \pm standardna devijacija

\section{RASPRAVA}

U ovome istraživanju pokazala se statistički povećana anksioznost $\mathrm{u}$ ispitanika kao trenutno stanje $\mathrm{u}$ odnosu na njihovu sklonost k anksioznosti. Slične su rezultate u svojim istraživanjima odnosa ispitne anksioznosti i anksioznosti kao osobine dobili Wachelka i Katz koristeći također Spielbergerov STAI. Prema dobivenim rezultatima kod ispitanika se pokazala veća anksioznost prije ispita nego nakon ispita. Ovakvi rezultati su vrlo slični rezultatima istraživanja provedenih u SAD-u i Velikoj Britaniji koji su pokazali da visoka ispitna anksioznost pogađa između $25 \%$ i $30 \%$ studenata (10). Ako se svemu navedenome dodaju i informacije prema kojima se u SAD-u $20 \%$ visoko ispitno anksioznih studenata ispisuje $\mathrm{s}$ fakulteta uslijed ponavljanih akademskih neuspjeha, te da je visoka razina ispitne anksioznosti povezana s niskim samopoštovanjem, padanjem razreda, kao i negativnim stavovima prema školi i studiranju, a što sve posljedično dovodi do ugrožavanja fizičkog i mentalnog zdravlja studenata, i to u obliku povećanog konzumiranja alkohola i ostalih opojnih droga, onda $20 \%$ studenata predstavlja značajnu brojku u vidu važnosti preveniranja ovakvih neželjenih oblika ponašanja (5). Također se pokazalo da je visoka razina ispitne anksioznosti povezana s niskim samopoštovanjem, padanjem godine, kao i negativnim stavovima prema školi i studiranju. Studenti s višom anksioznošću u ispitnoj situaciji imaju manju samoefikasnost prilikom polaganja ispita, više su zaokupljeni negativnim automatskim mislima i mislima koje pokazuju nedostatak motivacije i interesa (7).

Rezultati istraživanja pokazuju da, kada je u pitanju zastupljenost predispitne anksioznosti prema spolu, studenti ženskog spola pokazuju veću neugodnost i zabrinutost prije i za vrijeme ispita. Studentice se izjašnjavaju da imaju lošiju koncentraciju na testu, da ih sama pomisao na ispit uplaši, više nego studente. Također, kod studenata ženskog spola izraženi su tjelesni simptomi za vrijeme testa u smislu tahikardije, bolova u želudcu, preznojavanja, crvenila u licu. Slični rezultati su dobiveni i u drugim studijama koje su primjenjivale istu metodologiju. Tako Reteguiz u svom istraživanju ukazuje da kod studentica postoji statistički značajno viši skor na STAI upitniku ali i na obje njegove subskale (9). Kada se našoj metodologiji prilagode rezultati drugih studija, pronalazi se da je i u drugim istraživanjima ženski spol osjetljiviji kada je u pitanju predispitna anksioznost. Neki autori ovu razliku objašnjavaju time da je ženski spol spremniji da prizna svoju anksioznost za razliku od muškaraca a moguće je i da kod djevojaka postoji generalno izraženija anksioznost nego kod momaka (11). Zato se postavilo pitanje da li su zbog toga djevojke u većem 
hendikepu od muškaraca u odnosu na ishod ispita. Ipak, rezultati studija ukazuju da nema velike razlike $\mathrm{u}$ uspješnosti polaganja ispita u odnosu na postojanje simptoma predispitne anksioznosti (12).

Studenti s boljim prosjekom ocjena $u$ našem istraživanju su pokazali statistički veću ispitnu anksioznost $\mathrm{u}$ odnosu na druge ispitanike. Brojna istraživanja upućuju na to da perfekcionisti imaju tendenciju procjenjivanja događaja stresnijima nego što oni zaista jesu. Flett, Hewitt i Dyck su utvrdili razmjerno malu, ali značajnu pozitivnu povezanost između perfekcionizma i anksioznosti kao stanja i kao osobine ličnosti procijenjenih Spielbergerovim upitnikom anksioznosti kao stanja i osobine ličnosti (STAI) (11).

Prema načinu stanovanja tijekom studija otkrili smo veći stupanj anksioznosti kod studenata koji žive kao podstanari i u studentskom domu. Studenti su izloženi mnogim dodatnim stresovima kao što su ispunjavanje akademskih zahtjeva, stvaranje stabilnijih partnerskih veza, povećane financijske teškoće, usklađivanje obveza između obitelji i posla, te problemima vezanim uz odvajanje od poznate socijalne sredine zbog čega su osjetljiviji na probleme prilagodbe. Uključivanje u visokoškolsku instituciju otvara niz novih mogućnosti, međutim, ovisno o zrelosti, osobinama ličnosti, načinima suočavanja, socijalnoj potpori i životnim okolnostima, studenti se različito prilagođavaju na novi način života tijekom studiranja. Uzroci niske efikasnosti studiranja još nisu dovoljno istraženi, međutim, uz osobne karakteristike svakog studenta, niska efikasnost može biti posljedica i loših uvjeta učenja, nepovoljnih uvjeta rada i života studenata te nedovoljna motiviranost studenata zbog neizvjesnog zapošljavanja (8).

Za kraj treba spomenuti i ograničenja provedenog istraživanja. Iako je istraživanje nastojalo zahvatiti studente svih studijskih godina, rezultati istraživanja ne mogu se generalizirati na cijelu studentsku populaciju, kao ni na ostale dobne i obrazovne skupine. Svi prikupljeni podatci temeljeni su na samoprocjenama koje ne prikazuju nužno objektivno stanje što može predstavljati metodološki problem. Sudionici istraživanja su skloni davanju socijalno poželjnih odgovora te prikazivanja sebe $\mathrm{u}$ boljem svjetlu. Osim toga, postoji mogućnost da se sudionici pogrešno procjenjuju zbog nedovoljnog uvida $u$ vlastite osobine (8).

\section{ZAKLJUČAK}

Statistički značajno veća anksioznost postoji kod studenata prije ispita nego poslije ispita. Razina anksioznosti kao stanja ličnosti u ispitanika pokazala se statistički značajno veća u odnosu na anksioznost kao osobine ličnosti. Statistički značajno veća ispitna anksioznost postoji kod studentica, potom studenata s boljim prosjekom ocjena i onih koji ne stanuju kod roditelja tijekom studiranja.

Studijska godina fakulteta, materijalni status, navika pušenja cigareta, povremeno uzimanje alkoholnih pića i psihoaktivnih tvari nisu pokazali statistički značajnu povezanost $s$ ispitnom anksioznošću kod studenata.

\section{LITERATURA}

1. Ozen NS, Ercan I, Irgil E, Sigirli D. Anxiety prevalence and affecting factors among university students. Asia Pac J Public Health. 2010;22:12733.

2. Lymn JS, Mostyn A. Audience response technology: engaging and empowering non-medical prescribing students in pharmacology learning. BMC Med Educ. 2010;27:10-73.

3. Jakovljević M, i sur. Psihijatrija za studente stručnih zdravstvenih studija. Samobor: A.G. Matoš; 1995.

4. Cassady JC, Johnson RE. Cognitive test anxiety and academic performance. Contemp Educ Psychol. 2002;27:270-95.

5. Bravić, I. Ispitna anksioznost i perfekcionizam u funkciji spola i školskog postignuća. Diplomski rad. Split: Filozofski fakultet Sveučilišta u Splitu; 2001.

6. Mohorić T. Kognitivno-emocionalne odrednice akademskog postignuća studentata. Magistarski rad. Filozofski fakultet. Zagreb: Sveučilište u Zagrebu; 2006.

7. Cassady JC, Johnson RE. Cognitive test anxiety and academic performance. Contemp Educ Psychol. 2002;27:270-95. 
8. Horvat M. Evaluacija Upitnika anksioznosti kao stanja i osobine STAI. Diplomski rad. Zagreb: Odsjek za psihologiju Filozofskog fakulteta, Sveučilište u Zagrebu; 2002.

9. Wachelka D, Katz RC. Reducing test anxiety and improve academic self-esteem in high school and college students with learning disabilities. J Behav Therapy. 1999;30:191-8.

10. National Collaborating Centre for Mental Health. Management of panic disorder and general anxiety disorder in primary and secondary care. London: Nation Instit Clinic Excel; 2007.
11. Mohorić T. Kognitivno-emocionalne odrednice akademskog postignuća studentata. Magistarski rad. Filozofski fakultet. Zagreb: Sveučilište u Zagrebu; 2006.

12. Arambašić L. Anksioznost u ispitnim situacijama - pregled istraživanja. Revija za psihologiju. 1988;18:91-113. 


\title{
ANXIETY OF STUDENTS AT THE FACULTY OF HEALTH STUDIES IN MOSTAR BEFORE AND AFTER EXAMS
}

\author{
Oliver Ljubić ${ }^{1}$, Dragan Babić ${ }^{1,2}$ \\ ${ }^{1}$ Faculty of Health Studies, University of Mostar, \\ ${ }^{2}$ Clinic for Psychiatry, University Clinical Hospital Mostar, Bosnia and Herzegovina
}

\begin{abstract}
INTRODUCTION: Anxiety is a group of various medical conditions that are dominated by fear, anguish, tension or discomfort. It occurs in various life situations, and it is very common among students during exams.

OBJECTIVE: Examine the anxiety of students at the Faculty of Health Studies in Mostar, before and after exams.

SUBJECTS AND METHODS: The study included a sample of 200 students from all five study programmes at the Faculty of Health Studies in Mostar. The respondents were supposed to fill out the State-Trait Anxiety Inventory (STAI) on the day of exam. After completing the first part of the questionnaire, each patient individually agreed for another meeting after $24 \mathrm{~h}$, for the purposes of out filling the second part of the questionnaire.

RESULTS: 200 results were statistically treated. There were 88 male subjects (44.0\%) and 76 female subjects (51.6\%). The average age of patients was $22.9 \pm 1$.7. The average value of the response obtained on the scale of anxiety in patients prior to the test was $50.1 \pm 6.1$ points, while the scale of trait anxiety 24 hours after the exam was $48.6 \pm 7.1$ points, which proved to be statistically significant $(\mathrm{p}=0.020)$.

CONCLUSION: Significantly greater anxiety exists among students before the exam than after the exam. The level of state anxiety was statistically significantly higher than the level of trait anxiety.
\end{abstract}

Key words: anxiety, students, Faculty of Health Studies

Correspondence:

Oliver Ljubić, mag. med. tech.

e-mail: oliver_m0@hotmail.com 